\title{
The use of biological fabaceae resources of the cretaceous south of Russia in breeding on the example of the species Melilotus albus medik
}

\author{
V.M. Kosolapov ${ }^{1}$, V.I. Cherniavskih ${ }^{1,2,3,{ }^{*}, \text { E.V. Dumacheva }}{ }^{1,2,3}$, and L.M. Tseiko ${ }^{2}$ \\ ${ }^{1}$ Federal Williams Research Center of Forage Production \& Agroecology, 1 building, Scientific town, \\ Lobnya, Moscow region, 141055, Russia \\ ${ }^{2}$ All-Russian Research Institute of Phytopathology, 5 Ownership, Institute St., r.p. Big Vyazemy, \\ Odintsovo district, Moscow region, 143050, Russia \\ ${ }^{3}$ Belgorod State University, 85, Pobedy St., Belgorod, 308015, Russia
}

\begin{abstract}
The morpho-biological traits of the breeding sample POD $17 / 13$, created on the basis of genetic material of wild populations of $M$. albus of the Cretaceous south of the Central Russian Upland, were evaluated in comparison with the well-known zoned variety "Obskoy gigant". The purpose of breeding work is to obtain a combination in one genotype of high yield traits of feed mass and leaf coverage; high protein content and low fiber content while maintaining seed productivity at the standard level. Three sets of field experiment were carried out: in 2016, 2017 and 2018. The setting years were the first years of life for the biennial M. albus crop. Individuals of the POD $17 / 13$ breeding sample tend to increase the length of the growing season: by an average of 3.7 days in the first year of life, and by 7.3 days in the second year. According to the seed yield, the breeding sample M. albus POD 17/13 is at the standard level. In terms of protein content, the POD 17/13 variety significantly exceeds the standard in the first year of life by $6.8 \ldots 9.2 \%$, in the second - by $15.1 \ldots 19.2 \%$. At the same time, its herbage is more tender, since the fiber content in the aboveground mass is lower than that of the standard - in the first year of life - by $2.1 \ldots 7.1 \%$, in the second year of life $-6.9 . .9 .9 \%$. Thus, the POD 17/13 variety sample, created on the basis of the source material of wild populations of $M$. albus, is promising for obtaining a new variety based on it.
\end{abstract}

\section{Introduction}

The intensification of agricultural production in the Russian Federation requires a significant expansion of the assortment of cultivated forage crops, primarily due to the involvement of sparsely distributed species in production $[1,2]$.

Nevertheless, most often this causes difficulties associated with the lack of varieties, both resistant to unfavorable biotic and abiotic conditions of cultivation, and having stable and high seed productivity. There is a need to expand the assortment of sparsely distributed

\footnotetext{
${ }^{*}$ Corresponding author: cherniavskih@mail.ru
} 
crops, primarily species of herbs of the Fabaceae family. Scientists of the Belgorod State National Research University together with the leading centers of the Russian Academy of Sciences (the Federal Scientific Center of Fodder Production and Agroecology named after V.R. Williams, the All-Russian Research Institute of Phytopathology and others) conduct expedition, field and laboratory studies of biological resources of valuable legume species of the Cretaceous south of the Central Russian Upland to involve them in breeding programs to expand the assortment of perennial herbs for multipurpose use $[3,4,5]$.

Belgorod region, which is economically part of the Central Chernozem region of Russia, from the point of view of geographical location is located on the southeastern macroslope of the Central Russian Upland. It is characterized by a high degree of indentation of the territory by draws and natural landmarks. The region is characterized by a variety of soil and climatic conditions. The region is characterized by microzonality, a high degree of distribution of carbonate substrates and cretaceous outcrops, high degree of erosion processes development. It is characterized by high agricultural and industrial development $[6,7]$.

Due to the above features and the microclimatic conditions formed in them, as well as the presence of refugiums, the region is characterized by a high degree of flora endemism, its species diversity. The theory of formation of a secondary anthropogenic microgenesenter of synanthropic plant species formation in the unique conditions of the Cretaceous south of the Central Russian Upland is substantiated [8, 9].

On the basis of the mobilization of genetic resources of perennial grasses of the Fabaceae family growing in the ravine-draw complexes of the Cretaceous south of the Central Russian Upland, a number of varieties with multi-purpose value were obtained: fodder, nectareous, lawn, phytomeliorative, environment-improving, pharmaceutical, etc. These are varieties of species Trifolium repens L. - 'Krasnoyaruzhsky' and 'Ilek'; species $T$. pratense L. - 'Stepnyak'; Medicago varia L. - 'Krasnoyaruzhskaya 1', 'Krasnoyaruzhskaya 2', 'Alekseevskaya 1' [10].

An important area of domestic and foreign research is a breeding program with a biennial species of legumes Melilotus albus Medik. [11, 12, 13]. The M. albus species is known as a valuable high-protein salt-resistant forage crop, a high-quality nectariferous plant $[14,15,16]$. It is characterized by high rhizobial activity [17].

White sweet-clover is studied to increase the nutritional value of its aboveground mass by reducing the content of lignin, coumarin, etc. [18]. The breeding for the duration of flowering and increasing the plant leaf coverage is carried out [19]. Due to the intensive growth of biomass during the growing season, $M$. albus has the prospect of being used as biofuel [20].

In recent years, the interest in M. albus in the official pharmacopoeia has been increasing. The genetic structure of M. albus is being studied, including with the purpose to use its aboveground mass for the production of valuable medicinal substances [21, 22, 23]. The antimicrobial, antibacterial and antioxidant potential of M. albus is being studied [24]. Preparations based on $M$. albus are used in the treatment of a number of complex neurological diseases [25].

Considering the value and prospects of M. albus for agricultural production in the conditions of the Cretaceous south of the Central Russian Upland, more than 15 years ago, studies of the biological resources of its wild forms were started. As a result, separate forms and ecotypes were identified for a complex of valuable economic and useful traits (Fig. 1). A collection was created, which included both zoned varieties and forms of M. albus isolated in various ecotopes of the Belgorod region: on cretaceous outcrops of ravine-draw complexes, in floodplains of small rivers, on residential territories, etc. [9, 26].

As a result of many years of targeted breeding work in 2018, the M. albus variety 'Varvarovsky' was obtained and included in the register of varieties approved for use in the 
Russian Federation. The variety was bred by the polycross method. The initial material for its creation was selections from the varieties 'Obskoy gigant', 'Iney', individual selections from local populations of $M$. albus growing on the Cretaceous outcrops of the Belgorod region. In addition to the initial forms of the Varvarovsky variety, a breeding sample - POD $17 / 13$ was selected in the collection nursery for a number of economically useful indicators. The purpose of this study was to evaluate its morpho-biological characteristics and productivity in comparison with the well-known zoned variety 'Obskoy gigant'.

\section{Materials and Methods}

The climate of the Belgorod region is moderately continental [27]. The initial material, which served as the basis for a new breeding sample, was selected during the period of expeditions from 2003 to 2016, using geobotany and phytocenology methods to study wild coenopopulations of $M$. albus [28]. The main criteria for selection were the duration of flowering, leaf coverage, protein content in the aboveground mass, high potential seed productivity.

As a result of the work on the basis of the Laboratory of Biological Resources and Plant Breeding of Belgorod State University, a collection of wild forms, as well as zoned varieties of $M$. albus, was created, which included 156 numbers, including 63 samples of the working collection. Among all the numbers of the collection by 2016, the POD 17/13 number stood out for a set of economically useful traits.

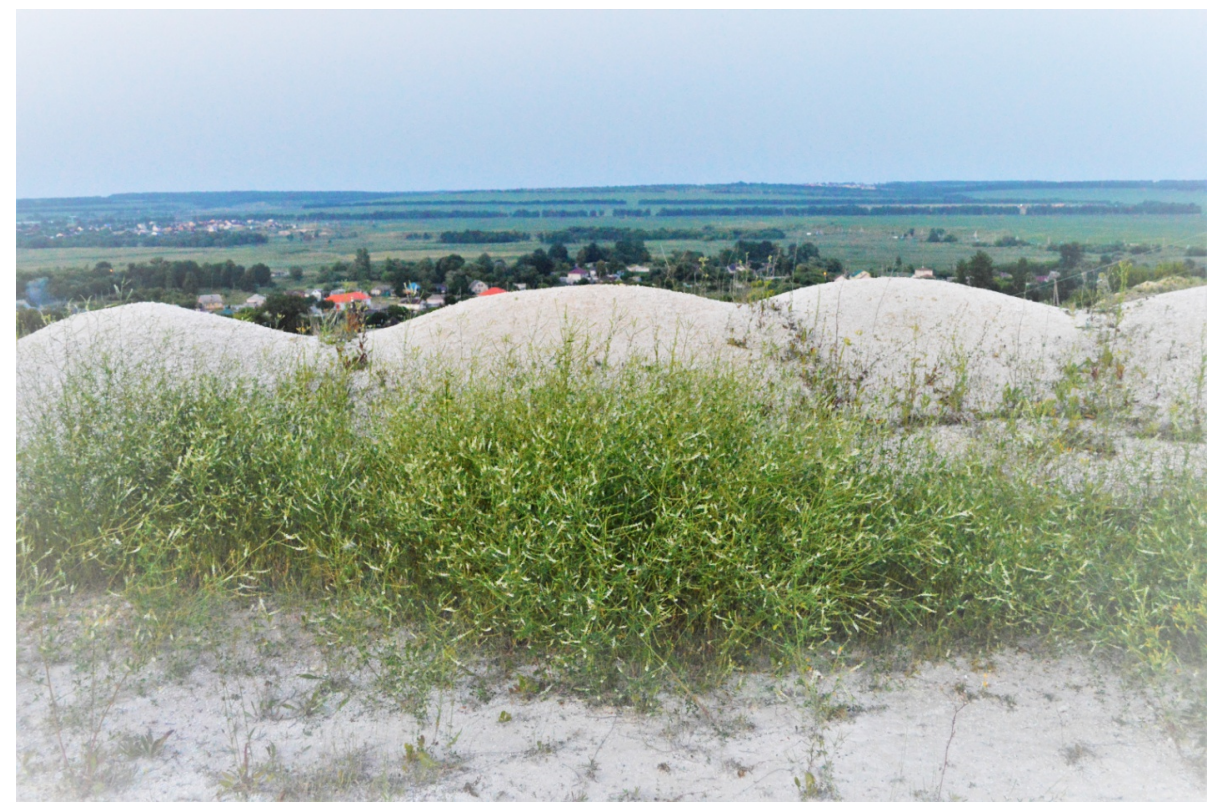

Fig. 1. Wild population of M. albus on Cretaceous outcrops (by Cherniavskii V.I.).

In 2016-2019, comparative tests of the POD 17/13 breeding sample with the zoned variety 'Obskoy gigant', adopted as a standard, were carried out on the experimental field, which was kindly provided by the individual entrepreneur Mavrodin Sergey Afanasievich (IE "Mavrodin S.A.") for conducting research (Fig. 2).

The experimental field is located in the village of Dragunskoye, Belgorod district, Belgorod region. The average annual precipitation is $553 \mathrm{~mm}$; the average annual temperature is $+6.3{ }^{\circ} \mathrm{C}$. The frost-free period is $8-9$ months. The height above sea level is $181 \mathrm{~m}$. 
The soil is typical chernozem, with an average content of humus according to Tyurin 4.9\% (GOST 26213-84); neutral pH sal. - 6.8 (GOST 26483-85); increased content of mobile phosphorus according to Chirikov - $120 \mathrm{mg} / \mathrm{kg}$ (GOST 26204-84); high content of exchangeable potassium - $180 \mathrm{mg} / \mathrm{kg}$ (GOST 26204-84).

The setting of the field experiment was carried out by the split plot method. The size of the accounting plot of the first order is $50 \mathrm{~m}^{2}$, the accounting plot of the second order is 25 $\mathrm{m}^{2}$ in 4-fold repetition. Sowing was carried out with a SZT- 3,6 seeder with a row spacing of $15 \mathrm{~cm}$. The seeding rate is $20 \mathrm{~kg} / \mathrm{ha}$.

Three sets of experiment were carried out: in 2016, 2017 and 2018. The setting years were the first years of life for the biennial M. albus crop. The green mass, dry matter and the length of the growing season were evaluated by standard methods during two years of testing. The length of the growing season was assumed to be equal to the length of the period before the mowing ripeness. In the second year of life, the plots were divided into 2 parts - on the accounting plot of the first order, mowing was carried out and the collection of green mass and dry matter was determined. On the second-order accounting plot, seed productivity was evaluated. The analysis of the green mass for feed value was carried out by standard methods: according to GOST 13496.4-84, the content of crude protein (\%) was determined; according to GOST 13496.2-84 - crude fiber (\%).

The results were processed by methods of mathematical statistics. When assessing the reliability of the difference in relative and average values for plant height, leaf coverage, protein and fiber content, the t-criterion was used, assuming that the difference is reliable at $\mathrm{t}_{\mathrm{f}}=2.0$ or more at a probability level of $\mathrm{P} \geq 95.5 \%$ [29].

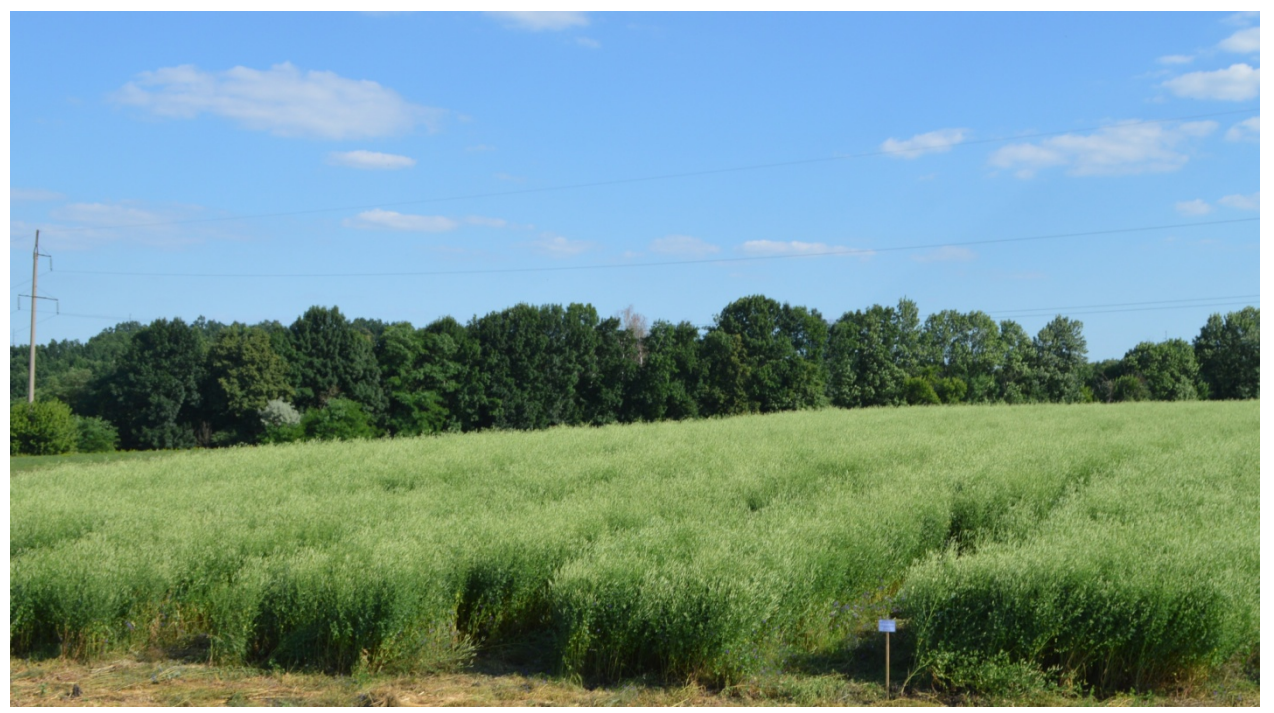

Fig. 2. Sowings of the M. albus variety POD $17 / 13$ of the second year of life at the breeding site of IE "Mavrodin S.A." (by Cherniavskih V.I.)

\section{Results and Discussion}

The purpose of our breeding work with the white sweet-clover was to achieve a combination in one genotype of such traits as high yield of fodder mass and leaf coverage; high protein content with a decrease in fiber content while maintaining seed productivity at the standard level. In other words, they sought to achieve the formation of a more tender white sweet-clover herbage with seed productivity at the standard level. 
Evaluation of the main morpho-biological traits of the new breeding specimen M. albus POD 17/13 showed that the individuals of the breeding specimen POD 17/13 have a tightly pressed rosette shape of spring aftergrowing. They form a semi-erect bush, with a height from 145.0 to $175.0 \mathrm{~cm}$. The root system is strong, well-developed, nodules are actively formed on the roots, providing plants with nitrogen (Fig. 3).

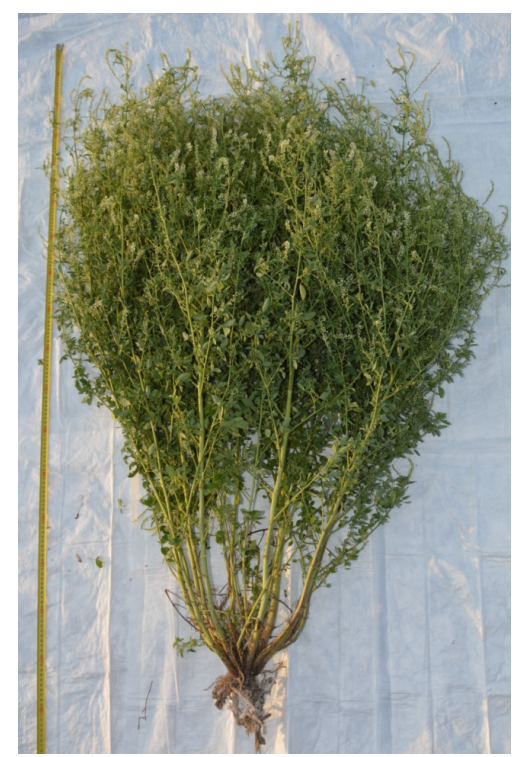

Fig. 3. General view of individuals of the breeding specimen M. albus POD 17/13 (by Cherniavskih V.I.).

There is no pubescence in the stems, the stem roughness is medium. Anthocyanin color of the nodes in the stems is weakly expressed.

The stems have a high branching, the average number of internodes is 21.0 , while their number varies from 18.0 to 25.0 internodes.

The bushiness of individuals of the POD 17/13 breeding sample is strong - they form up to 10-17 stems per bush.

The leaf coverage of individuals is uniform, the leaf mass ranges from 56.0 to $70.0 \%$ of the total weight of individuals.

The leaves of the middle tier have a pronounced green color, obovate shape, length from 3.4 to $5.1 \mathrm{~cm}$. They were covered with a week waxy coating. There is no pubescence in the leaves. They are soft to the touch.

Stipules of the middle tier are green, narrowly lanceolate in shape with weak pubescence.

Inflorescence is a loose raceme with an elongated tip, has a length from 7.0 to $15.0 \mathrm{~cm}$. The flowers are white (Fig. 4).

Individuals of the POD 17/13 breeding sample form egg-shaped beans, ranging in size from 2.2 to $3.2 \mathrm{~mm}$. The beans contain seeds ranging in size from 1.4 to $1.9 \mathrm{~mm}$, oval in shape, yellow-green in color.

The results of the evaluation of seed and feed productivity, as well as the duration of the growing season in M. albusvariety samples of the first and second years of life are shown in Table 1.

Individuals of the POD 17/13 breeding sample tend to increase the length of the growing season: by an average of 3.7 days in the first year of life, and by 7.3 days in the second year. This is accompanied by an increase in the flowering period. At the same time, 
the seed ripening period is also shifted to a later date. According to the seed yield, the $M$. albus breeding sample POD 17/13 is at the standard level, but exceeds it in terms of aboveground productivity. At the same time, according to green mass and dry matter yield in the first year of life, the POD 17/13 breeding sample did not have a pronounced advantage over the standard. But in the second year of life, it significantly exceeded it by $23.6 . .28 .9 \%$ for green mass yield and by $27.9 \ldots 31.1 \%$ for the collection of dry matter.

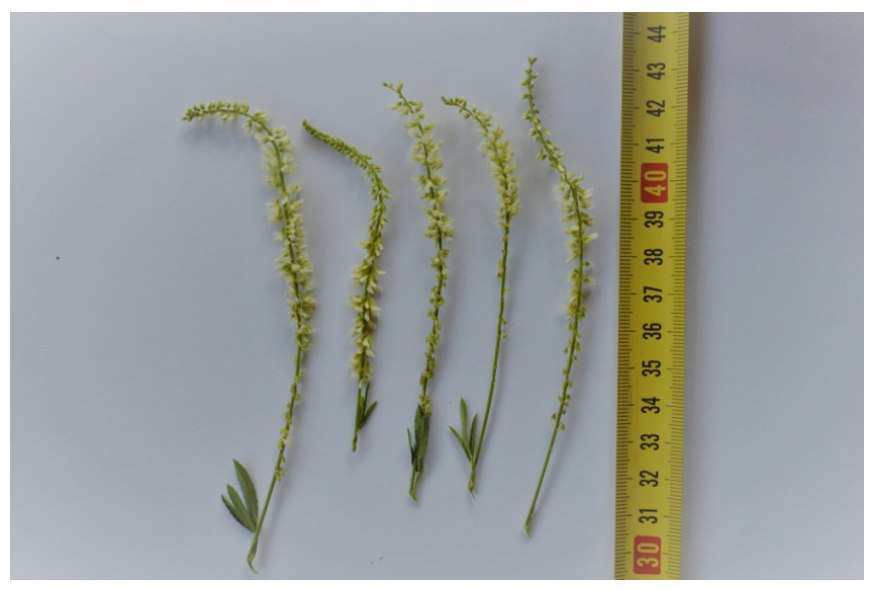

Fig. 4. Inflorescences of the M. albus breeding sample POD 17/13 (by Cherniavskih V.I.).

Table 1. The duration of the growing season and the results of the evaluation of feed and seed productivity in M. albus variety samples of the first and second years of life.

\begin{tabular}{|c|c|c|c|c|c|c|}
\hline \multirow{3}{*}{ Variety sample } & \multicolumn{6}{|c|}{ Years of research } \\
\hline & \multicolumn{3}{|c|}{ first year of life } & \multicolumn{3}{|c|}{ second year of life } \\
\hline & 2016 & 2017 & 2018 & 2017 & 2018 & 2019 \\
\hline \multicolumn{7}{|c|}{ Vegetation period, days } \\
\hline POD $17 / 13$ & 110 & 112 & 109 & 67 & 71 & 69 \\
\hline 'Obskoy gigant', standard & 106 & 108 & 106 & 62 & 61 & 62 \\
\hline \pm to standard & 4 & 4 & 3 & 5 & 10 & 7 \\
\hline \multicolumn{7}{|c|}{ Yield of green mass, $\mathrm{t} / \mathrm{ha}$} \\
\hline POD $17 / 13$ & 14.48 & 16.72 & 16.79 & 38.54 & 36.70 & 38.23 \\
\hline 'Obskoy gigant', standard & 15.60 & 14.91 & 16.32 & 30.64 & 29.69 & 29.67 \\
\hline LSD 05 & 0.48 & 0.37 & 0.56 & 0.59 & 0.72 & 0.68 \\
\hline \pm to standard & -1.12 & 1.81 & 0.47 & 7.90 & 7.01 & 8.56 \\
\hline \multicolumn{7}{|c|}{ Yield of dry matter, $\mathrm{t} / \mathrm{ha}$} \\
\hline POD $17 / 13$ & 2.88 & 3.34 & 3.51 & 9.24 & 8.65 & 9.02 \\
\hline 'Obskoy gigant', standard & 2.96 & 3.28 & 3.26 & 7.15 & 6.76 & 6.88 \\
\hline LSD 05 & 0.09 & 0.09 & 0.11 & 0.21 & 0.19 & 0.16 \\
\hline \pm to standard & -0.08 & 0.06 & 0.25 & 2.09 & 1.89 & 2.14 \\
\hline \multicolumn{7}{|c|}{ Seed yield, $\mathrm{kg} / \mathrm{ha}$} \\
\hline POD $17 / 13$ & - & - & - & 685.0 & 674.0 & 714.0 \\
\hline
\end{tabular}




\begin{tabular}{|l|c|c|c|c|c|c|}
\hline 'Obskoy gigant', standard & - & - & - & 710.0 & 681.0 & 729.0 \\
\hline LSD 05 & - & - & - & 41.2 & 43.1 & 43.1 \\
\hline \pm to standard & - & - & - & -25.00 & -7.00 & -15.00 \\
\hline
\end{tabular}

High indicators of aboveground productivity are associated with the fact that individuals of the POD 17/13 variety sample significantly exceeded the standard in leaf coverage in the first year of life by $6.8 \ldots 10.8 \%$, in the second - by $19.4 \ldots 23.0 \%$ (Table 2 ).

At the same time, the height of the POD 17/13 variety sample bushes was at the standard level or slightly inferior to it.

Table 2. Height and leaf coverge in M. albus variety samples of the first and second years of life.

\begin{tabular}{|c|c|c|c|c|c|c|}
\hline \multirow{3}{*}{ Variety sample } & \multicolumn{6}{|c|}{ Years of research } \\
\hline & \multicolumn{3}{|c|}{ first year of life } & \multicolumn{3}{|c|}{ second year of life } \\
\hline & 2016 & 2017 & 2018 & 2017 & 2018 & 2019 \\
\hline \multicolumn{7}{|c|}{ Plant height before harvesting, $\mathrm{cm}$} \\
\hline POD $17 / 13$ & $\begin{array}{c}82.3 \pm 3.2 \\
1 \\
\end{array}$ & $78 \pm 2.94$ & $\begin{array}{c}88.3 \pm 3.1 \\
2 \\
\end{array}$ & $145 \pm 4.01$ & $152 \pm 7.19$ & $175 \pm 4.03$ \\
\hline $\begin{array}{l}\text { 'Obskoy gigant', } \\
\text { standard }\end{array}$ & $\begin{array}{c}82.0 \pm 2.6 \\
0 \\
\end{array}$ & $\begin{array}{c}80.0 \pm 2.3 \\
7 \\
\end{array}$ & $\begin{array}{c}88.1 \pm 2.4 \\
1 \\
\end{array}$ & $158 \pm 4.85$ & $182 \pm 9.28$ & $178 \pm 5.16$ \\
\hline $\mathrm{t}$ & 0.07 & 0.53 & 0.05 & 2.07 & 2.55 & 0.46 \\
\hline \multicolumn{7}{|c|}{ Leaf coverage, $\%$} \\
\hline POD $17 / 13$ & $\begin{array}{c}58.6 \pm 1.2 \\
3\end{array}$ & $\begin{array}{c}57.9 \pm 2.1 \\
4\end{array}$ & $\begin{array}{c}56.8 \pm 1.3 \\
8\end{array}$ & $\begin{array}{c}66.3 \pm 3.3 \\
6\end{array}$ & $\begin{array}{c}65.8 \pm 4.0 \\
1\end{array}$ & $\begin{array}{c}65.8 \pm 3.7 \\
7\end{array}$ \\
\hline $\begin{array}{l}\text { 'Obskoy gigant', } \\
\text { standard }\end{array}$ & $\begin{array}{c}52.9 \pm 1.5 \\
7\end{array}$ & $52 \pm 1.66$ & $\begin{array}{c}53.2 \pm 1.1 \\
9\end{array}$ & $\begin{array}{c}53.9 \pm 2.9 \\
3\end{array}$ & $\begin{array}{c}54.1 \pm 3.1 \\
7\end{array}$ & $\begin{array}{c}55.1 \pm 2.9 \\
9\end{array}$ \\
\hline $\mathrm{t}$ & 2.86 & 2.18 & 1.98 & 2.78 & 2.29 & 2.22 \\
\hline
\end{tabular}

Since the white sweet-clover is primarily a valuable fodder crop, the green mass quality determines the economic usefulness of the variety samples and the prospects for their further study. As studies have shown, the quality of the green mass of the POD 17/13 breeding sample is significantly superior to the 'Obskoy gigant' variety (Table 3 ).

Table 3. The protein and fiber content in the green mass of M. albus variety samples of the first and second years of life.

\begin{tabular}{|c|c|c|c|c|c|c|}
\hline \multirow{3}{*}{ Variety sample } & \multicolumn{6}{|c|}{ Years of research } \\
\hline & \multicolumn{3}{|c|}{ first year of life } & \multicolumn{3}{|c|}{ second year of life } \\
\hline & 2016 & 2017 & 2018 & 2017 & 2018 & 2019 \\
\hline \multicolumn{7}{|c|}{ Crude protein content, $\%$} \\
\hline POD $17 / 13$ & $\begin{array}{c}20.20 \pm 0.3 \\
3\end{array}$ & $\begin{array}{c}20.10 \pm 0.4 \\
2\end{array}$ & $\begin{array}{c}20.10 \pm 0.5 \\
3\end{array}$ & $\begin{array}{c}22.90 \pm 0.6 \\
2\end{array}$ & $\begin{array}{c}22.00 \pm .0 .6 \\
0\end{array}$ & $\begin{array}{c}23.00 \pm 0.6 \\
3\end{array}$ \\
\hline $\begin{array}{l}\text { 'Obskoy gigant', } \\
\text { standard }\end{array}$ & $\begin{array}{c}18.90 \pm 0.3 \\
7 \\
\end{array}$ & $\begin{array}{c}18.50 \pm 0.3 \\
9 \\
\end{array}$ & $\begin{array}{c}18.40 \pm 0.4 \\
1 \\
\end{array}$ & $\begin{array}{c}19.20 \pm 0.5 \\
0 \\
\end{array}$ & $\begin{array}{c}19.10 \pm 0.4 \\
8 \\
\end{array}$ & $\begin{array}{c}19.80 \pm 0.5 \\
9 \\
\end{array}$ \\
\hline $\mathrm{t}$ & 2.63 & 2.77 & 2.53 & 4.65 & 4.80 & 3.71 \\
\hline \multicolumn{7}{|c|}{ Crude fiber content, $\%$} \\
\hline POD $17 / 13$ & $\begin{array}{c}22.10 \pm 0.5 \\
2 \\
\end{array}$ & $\begin{array}{c}23.40 \pm 0.9 \\
6 \\
\end{array}$ & $\begin{array}{c}23.10 \pm 0.3 \\
1 \\
\end{array}$ & $\begin{array}{c}22.90 \pm 0.5 \\
6 \\
\end{array}$ & $\begin{array}{c}22.10 \pm 0.6 \\
6 \\
\end{array}$ & $\begin{array}{c}22.70 \pm 0.8 \\
7 \\
\end{array}$ \\
\hline
\end{tabular}




\begin{tabular}{|c|c|c|c|c|c|c|}
\hline $\begin{array}{l}\text { 'Obskoy gigant', } \\
\text { standard }\end{array}$ & $\begin{array}{c}23.80 \pm 0.6 \\
6\end{array}$ & $\begin{array}{c}23.90 \pm 0.8 \\
7\end{array}$ & $\begin{array}{c}24.20 \pm 0.4 \\
1\end{array}$ & $\begin{array}{c}24.60 \pm 0.6 \\
0\end{array}$ & $\begin{array}{c}24.05 \pm 0.6 \\
4\end{array}$ & $\begin{array}{c}25.20 \pm 0.7 \\
2\end{array}$ \\
\hline $\mathrm{t}$ & 2.02 & 0.39 & 2.14 & 2.07 & 2.12 & 2.21 \\
\hline
\end{tabular}

In terms of protein content, the POD 17/13 variety significantly exceeds the standard in the first year of life by $6.8 \ldots 9.2 \%$, in the second - by $15.1 \ldots 19.2 \%$. At the same time, its herbage is more tender, since the fiber content in the aboveground mass is lower than that of the standard - in the first year of life - by $2.1 \ldots 7.1 \%$, in the second year of life $6.9 . . .9 .9 \%$.

\section{Conclusion}

The Cretaceous south of the Central Russian Upland is a source of valuable biological resources for the creation of collections of genetic material and its further use in the breeding of cultivated plants.

M. albus populations formed in ravine-draw complexes and on Cretaceous outcrops are valuable genetic sources of economically valuable traits. Forms, highly productive, wellleafed with high bushiness and low growth are of particular interest.

The POD 17/13 variety sample, created on the basis of the source material of wild populations of $M$. albus, may be promising for obtaining a new variety based on it.

\section{References}

1. V. Kosolapov, V. Rud, A. Korshunov, I. Savchenko, F. Switala, W. Hogland, IOP Conference Series: Earth and Environmental Science, 390 (1) (2019) DOI: 10.1088/1755-1315/390/1/012010

2. V. M. Kosolapov, S. I. Kostenko, Yu. S. Tyurin, E. Z. Shamsutdinova, Yu. M. Piskovskii, IOP Conference Series: Earth and Environmental Science (2021) DOI: 10.1088/1755-1315/663/1/012022.

3. V. I. Chernyavskikh, E. V. Dumacheva, N. I. Sidelnikov, F. N. Lisetsky, L. Ch. Gagieva, Indian Journal of Ecology 46(2), 221-226 (2019)

4. V. M. Kosolapov, V. I. Cherniavskih, S. I. Kostenko, Vavilov Journal of Genetics and Breeding 25(4), 401-407 (2021) DOI 10.18699/VJ21.044

5. V. I. Chernyavskikh, E. V. Dumacheva, F. N. Lisetsky, B. G. Tsugkiev, L. Ch. Gagieva, Bioscience Biotechnology Research Communications 12(2), 203-210 (2019)

6. N S Kukharuk, L G Smirnova, S V Kalugina, M A Polschina, V I Chernyavsky, International Journal of Green Pharmacy 11(3), 626-630 (2017)

7. E. V. Dumacheva, V. I. Chernyavskikh, Kormoproizvodstvo 4, 8-11 (2014)

8. V. I. Cherniavskih, N. I. Sidelnikov, E. V. Dumacheva, Z. A. Borodaeva, T. N. Glubsheva, A. A. Gorbacheva, O. V. Vorobyova, S. Korolkova, EurAsian Journal of BioSciences 13(2), 845-849 (2019)

9. V I Chernyavskikh, E V Dumacheva, Successes of modern natural science, 1, 63-68 (2019) DOI: 10.17513/use.37038

10. V. I. Chernyavskih, A. G. Titovsky, R. A. Sharko, O. V. Shinkarenko, E. V. Dumacheva, Achievements in science and technology AIC 12, 14-17 (2012)

11. G. Fagúndez, Argentina Palynology 40(3), 308-321 (2016)

12. P. Sowa, M. Tarapatskyy, C. Puchalski, et al., Food Measure 13, 1748-1754 (2019) https://doi.org/10.1007/s11694-019-00092-w 
13. V. P. Naumkin, N. A. Shiryaeva, Beekeeping 2, 24-27 (2020) DOI: https://doi.org/1 0.30906/0869-2092-2019-82-12-19-22.

14. O. A. Ryazanova, Beekeeping 3, 4-6 (2018)

15. Yu. V. Kozyaychev, B. A. Tkhorikov, Agricultural Economics of Russia 5, 54-59 (2020) DOI: 10.32651/205-54

16. J. M. Zabala, L. Marinoni, J. A. Giavedoni, et al. Euphytica 214, 22 (2018) https://doi.org/10.1007/s10681-017-2031-0

17. L F Minnebaev, E V Kuzina, G F Rafikova, I O Chanyshev, O N Loginov, Agricultural Biology 54(3), 481-493 (2019) DOI: 10.15389/agrobiology.2019.3.481rus

18. L. Chen, F. Wu, J. Zhang, Plants 10(2), 303 (2021) https://doi.org/10.3390/pla nts 10020303

19. J. M. Zabala, G. Schrauf, J. Baudracco, J. Giavedoni, O. Quaino, P. Rush, Desr. Crop \& pasture science 63(4), 370-376 (2012) DOI: 10.1071/CP11326

20. A. Kintl, J. Elbl, T. Vítěz, M. Brtnický, J. Skládanka, T. Hammerschmiedt, M. Agronomy 10(9), 1407 (2020) https://doi.org/10.3390/agronomy10091407

21. M. Del Villar, R. Rivas, A. Peix, P. F. Mateos, E. Martínez-Molina, P. Van Berkum, A. Willems, E. Velázquez, FEMS microbiology letters 282(2), 273 (2008) DOI: 10.1111/j.1574-6968.2008.01139.x

22. Z. Ouyang, Y. Wang, T. Ma, G. Kanzana, F. Wu, J. Zhang, Plants 10(5), 890 (2021) https://doi.org/10.3390/plants 10050890

23. J. L. Ingham, Zeitschrift für Naturforschung 32(5-6), 449-452 (2014) DOI: 10.1515/znc-1977-5-625

24. O. D. Stefanović, J. D. Tešić, L. R. Čomić, Yàowù shípǐn fēnxī 23(3), 417-424 (2015) DOI: 10.1016/j.jfda.2015.01.003.

25. P. P. Shchetinin, V. V. Udut, V. P. Demkin, A. P. Shchetinina, Russian Journal of Experimental and Clinical Pharmacology 82(12), 19-22 (2019) DOI: 10.30906/08692092-2019-82-12-19-22.

26. V. I. Cherniavskih, E. V. Dumacheva, Z. A. Borodaeva, A. A. Gorbacheva, E. N. Horolskaya, N. V. Kotsareva, S. V. Korolkova, L. C. Gagieva, EurAsian Journal of BioSciences 13(2), 733-737 (2019)

27. F. N. Lisetskiy, V. A. Peresadko, S. V. Lukin, A. N. Petin, Atlas «Natural Resources and Ecological State of the Belgorod region», 180 (Belgorod, Belgorod Regional Printing House, 2005)

28. E. M. Lavrenko, A. A. Korchagina, Field geobotany, Methodical management, Section: Botany-Geobotanic, 4, 336 (Moscow: Russian Academy of Sciences of the USSR, 1972)

29. B. A. Dospekhov, Field experience methodology (with basic statistical processing of research results), 352 (M.: Print on Demand, 2012) 